\title{
Notes on courtship, egg-laying site, and defensive behavior of Epipedobates flavopictus (Anura, Dendrobatidae) from two mountain ranges of central and southeastern Brazil
}

\author{
Luís Felipe Toledo ${ }^{1}$, Lorena Dall’Ara Guimarães², Leôncio Pedrosa Lima ${ }^{2,3}$, Rogério P. \\ Bastos $^{2}$, and Célio Fernando Baptista Haddad ${ }^{1}$ \\ 1 Departamento de Zoologia, Instituto de Biociências, Universidade Estadual Paulista, Caixa Postal 199, 13506-970, \\ Rio Claro, São Paulo, Brazil. E-mail: toledo@rc.unesp.br. \\ 2 Departamento de Biologia Geral, Instituto de Ciências Biológicas, Universidade Federal de Goiás, Brazil. \\ ${ }^{3}$ Centro Nacional de Conservação e Manejo de Répteis e Anfíbios, Instituto Brasileiro do Meio Ambiente e dos \\ Recursos Naturais Renováveis, Goiânia, Goiás, Brazil.
}

Keywords: Anura, Dendrobatidae, Epipedobates flavopictus, egg-laying site, defensive behavior, courtship call, rock fields.

Epipedobates flavopictus (Lutz, 1925) is a member of the E. pictus species group (Silverstone 1976) that can be found in the Brazilian states of Minas Gerais, Goiás, Tocantins, Pará, and Maranhão (Frost 2004). This species has been under taxonomic discussion recently (Haddad and Martins 1994) but little information is available on its reproductive biology. Haddad and Martins (1994) have described its advertisement call, morphology of tadpoles and adults. It was also reported that males call from rock crevices at creek margins in rock fields, a common formation of central Brazil (Haddad and Martins 1994). There is also an indication that this species could perform deimatic behavior, similarly to Pleurodema brachyops, but no descriptions were provided (see Martins 1989, where E. flavopictus is treated in the genus Dendrobates). Herein, we describe the

Received 17 July 2004.

Accepted 12 November 2004.

Distributed December 2004. oviposition site, the egg-masses, the courtship call, and the deimatic behavior associated to parental care exhibited by one individual of $E$. flavopictus.

Field observations were made on 8 November 1989, at Municipality of Santana do Riacho, Serra do Cipó, state of Minas Gerais,

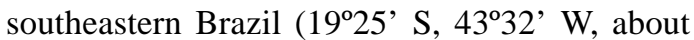
$800 \mathrm{~m}$ above sea level), and on 17 and 18 December 2003 at the Vale da Lua, Municipality of Alto Paraíso, Chapada dos Veadeiros, state of Goiás, central Brazil (14 $11^{\circ}$ ' S, $47^{\circ} 47^{\prime}$ W, about $905 \mathrm{~m}$ above sea level). Adult specimens, tadpoles, and eggs were collected and measured with a digital caliper to the nearest $0.01 \mathrm{~mm}$. The specimens were deposited at Célio F. B. Haddad anuran collection (CFBH), Departamento de Zoologia, Universidade Estadual Paulista, Rio Claro, State of São Paulo, Brazil. Tadpoles were staged according to Gosner (1960) and measured according to Altig (1970). Vocalizations were recorded with a Marantz PMD222 tape recorder and a Sennheiser MT80 microphone. 


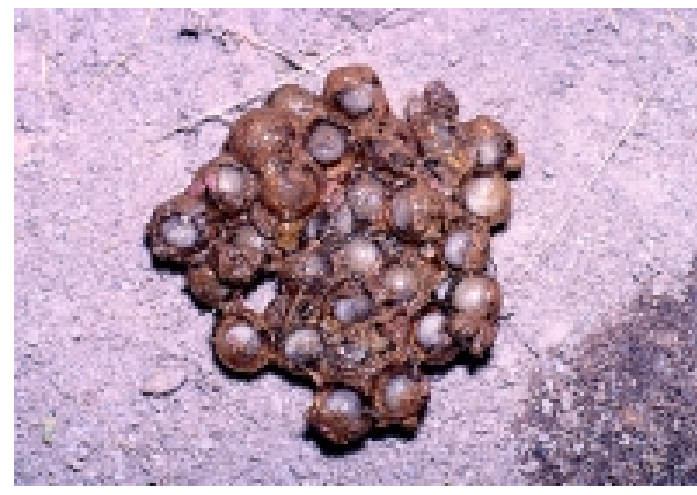

Figure 1-Egg-mass of Epipedobates flavopictus collected at Vale da Lua, municipality of Alto Paraíso, State of Goiás, central Brazil.

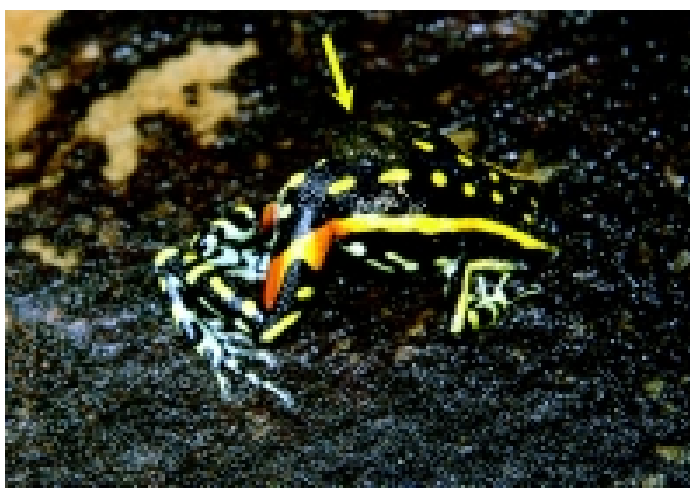

Figure 2 - Adult male Epipedobates flavopictus with tadpoles on dorsum (indicated by an arrow) and exhibiting the reddish femoral stripes of its legs after being disturbed. Individual observed at Santana do Riacho, Serra do Cipó, State of Minas Gerais, southeastern Brazil.

in different stages of development, suggesting that they were not laid on the same day. One of the egg-masses contained 31 eggs measuring $4.78 \pm 0.31 \mathrm{~mm}(4.19-5.21, \mathrm{~N}=10)$ in diameter (considering the gelatinous capsules). The other clutch had 24 eggs. One of the egg-masses lasted one week until the simultaneous hatching of the tadpoles. Just before hatching, the eggs had a mean diameter of $6.64 \pm 0.77 \mathrm{~mm}$ (5.54-7.57, $\mathrm{N}=6$ ). After emerging, the tadpoles were between the stages 21 and 24 and measured $4.04 \pm 0.08 \mathrm{~mm}(3.96-4.2, \mathrm{~N}=9)$ in body length, and $7.22 \pm 0.52 \mathrm{~mm}(6.38-7.82$, $\mathrm{N}=9$ ) in tail length.

An adult male with 18 tadpoles on his dorsum was found at Serra do Cipó. This number of tadpoles could represent an entire clutch as the tadpoles of one clutch hatch at the same time. Upon handling disturbance for taking pictures, the male raised his body and stretched his legs backwards exhibiting the bright and reddish femoral stripes (Figure 2), a behavior that can be interpreted as deimatic, functioning as defense against visually oriented predators (Martins 1989). Furthermore, out of 11 males handled, only the single one with tadpoles on the ground (Figure 1), approximately $10 \mathrm{~cm}$ from 
dorsum exhibited this deimatic behavior, hence it could be related to parental care. Defensive behaviors closely related with parental care had been previously reported for some species in two leptodactylid genus (Vaz-Ferreira and Gehrau 1975, Giaretta and Cardoso 1995, Vaira 1997, Martins 2001).

\section{Acknowledgements}

The authors are grateful to Cynthia P. A. Prado and two anonymous reviewers for comments on the manuscript, RAN-IBAMA for the collection license conceded (number 02001.002792/98-03), and CAPES, CNPq, and Biota FAPESP for providing grants to the Herpetology lab.

\section{References}

Altig, R. 1970. A key to the tadpoles of the continental United States and Canada. Herpetologica 26: 180207.

Frost, D. R. 2004. Amphibian Species of the World - an online reference. URL: http://research.amnh.org/ herpetology/amphibia/index.html. Captured on 8 November 2004.
Giaretta, A. A. and A. Cardoso. 1995. Reproductive behavior of Cycloramphus dubius Miranda-Ribeiro (Amphibia, Anura, Leptodactylidae). Revista Brasileira de Zoologia 12: 229-232.

Gosner, K. L. 1960. A simplified table for staging anuran embryos and larvae with notes on identification. Herpetologica 16: 183-190.

Haddad, C. F. B. and M. Martins. 1994. Four species of Brazilian poison frogs related to Epipedobates pictus (Dendrobatidae): taxonomy and natural history observations. Herpetologica 50: 282-295.

Haddad, C. F. B., G. V. Andrade and A. J. Cardoso. 1988. Anfíbios do Parque Nacional da Serra da Canastra, Estado de Minas Gerais. Brasil Florestal 64: 9-20.

Martins, I. 2001. Parental care behaviour in Leptodactylus podicipinus (Cope, 1862) (Anura, Leptodactylidae). Herpetological Journal 11: 29-32.

Martins, M. 1989. Deimatic behavior in Pleurodema brachyops. Journal of Herpetology 23: 305-307.

Silverstone, P. A. 1976. A revision of the poison arrow frogs of the genus Phyllobates Birbon in Sagra (Family Dendrobatidae). Natural History Museum of Los Angeles, Scientific Bulletin 27: 1-53.

Vaira, M. 1997. Leptodactylus bolivianus (NCN). Behavior. Herpetological Review 28: 200.

Vaz-Ferreira, R. and A. Gehrau. 1975. Comportamiento epimeletico de la rana comun, Leptodactylus ocellatus (L.) (Amphibia, Leptodactylidae) I. Atencion de la cria y actividades alimentares y agressivas relacionadas. Physis, seccion B 34: 1-14. 